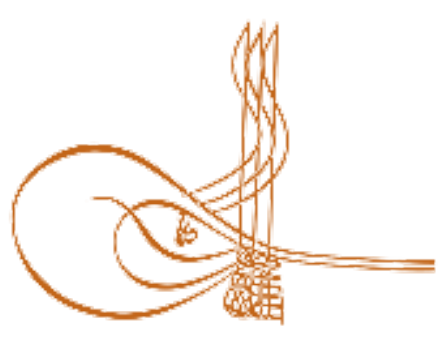

www.turkishstudies.net/education
Turkish Studies - Educational Sciences

eISSN: 2667-5609

Research Article / Araștırma Makalesi

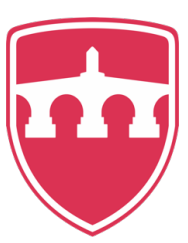

INTERNATIONAL BALKAN

UNIVERSITY Sponsored by IBU

\title{
Görsel Sanatlar Dersi Kaygı Ölçeği: Geçerlik ve Güvenirlik Çalışmasıı ${ }^{1}$
}

Vlsual Art Lesson Anxiety Scale: A Validity and Reliability Study

\author{
Yahya Hiçyılmaz* - Fatih Karip**
}

\begin{abstract}
In this study, it was aimed to develop a scale whose validity and reliability are provided in order to determine the concerns of secondary school students about Visual Arts lesson. The 5-point likert draft Visual Arts lesson anxiety scale (VALAS) consisting of 23 items was applied to 333 students in 5th, 6th, 7th and 8th grade in different schools in Ağrı city center in the 2018-2019 academic year. After the exploratory factor analysis (EFA), a measurement instrument consisting of 12 items and 2 sub-dimensions was obtained. The first dimension was named as "anxiety towards the course", and the second dimension was named as "the anxiety towards the process." It is seen that the first dimension consists of 6 items and the factor load value is between .620 and .818 , and the second dimension consists of 6 items and it has a factor load value between .611 and .773 . Factor common variances were observed to be between .377 and .675 . As a result of the analyzes, it was seen that the sacle explains $51,338 \%$ of the total variance. In addition, it was determined that the eigenvalues of each dimension were greater than 1 and had a variance of $33,541 \%$ and $17,797 \%$, respectively. Confirmatory Factor Analysis (CFA) was performed to determine the degree to which the determined structure was confirmed. In this respect, data from a different student group of 282 people were collected for CFA. As a result, the research group consisted of 615 students. As a result of the CFA, the suitability of the factor structures obtained from EFA was demonstrated. The Cronbach Alpha coefficient of the VALA scale was found to be 810 .
\end{abstract}

Structured Abstract: The Turkish language association defines anxiety as the uneasiness, sadness, worried thought and sorrow that the individuals and the social clusters feel in case of the possibility that their strong desires or motives cannot be realized (tdk.gov.tr). Although it is defined as an emotion stimulating the individual against the dangers coming from outside and stimulateing the individuals towards constructive behaviors in some definitions (Çavuş \& Günbatar, 2008), anxiety is an unwanted situation that makes it difficult for us to learn by creating stress, fear and concern in the individual. Therefore, it is necessary to try

${ }^{1} \mathrm{Bu}$ araştırmanın verileri 2018-2019 eğitim-öğretim yılı güz döneminde toplanmıştır.

*Dr. Öğr. Üyesi, Van Yüzüncü Y1l Üniversitesi, Eğitim Fakültesi, Güzel Sanatlar Eğitimi

Assist. Prof. Dr., Van Yuzuncu Yil University, Faculty of Education, Fine Arts Education

ORCID 0000-0003-3453-9998

yahya-04@windowslive.com

**Dr. Öğr. Üyesi, Ağrı İbrahim Çeçen Üniversitesi, Eğitim Fakültesi, Güzel Sanatlar Eğitimi

Assist. Prof. Dr. Agri İbrahim Cecen University, Faculty of Education, Fine Arts Education

ORCID 0000-0002-8957-1568

fkarip@agri.edu.tr

Cite as/ Atıf: Hiçyılmaz, Y. \& Karip, F. (2020). Görsel sanatlar dersi kaygı ölçeği: geçerlik ve güvenirlik çalışması,

Turkish Studies - Education, 15(2), 897-909. https://dx.doi.org/10.29228/TurkishStudies.41759

Received/Geliş: 13 February/ Şubat 2020

Accepted/Kabul: 28 April/Nisan 2020

Checked by plagiarism software

Copyright (C) INTAC LTD, Turkey

Published/Yayın: 30 April/Nisan 2020

CC BY-NC 4.0 
to determine the students' concerns about visual arts lesson, to examine all aspects of learning environments, and to identify the problems encountered and the ways to solve these problems.

When the related literature is examined, it is seen that there are many anxiety scales for different disciplines (Özdemir \& Gür, 2011; Kağıtçı \& Kurbanoğlu, 2013; Mutlu \& Söylemez, 2018; Yıldırım, 2015). There are also limited number of anxiety studies towards visual arts course in Turkey (Dilmaç, 2010; Hiçyılmaz, İnam Karahan \& Adanır, 2018; Temiz, 2011; Yurdakul, 2006). However, there is no scale measuring the anxiety levels of secondary school students towards the visual arts course. In this respect, it is important to develop an anxiety scale for the visual arts course of secondary school students.

This study, which was conducted in order to determine the anxiety levels of secondary school students about Visual Arts course, is a basic research study. In this study, data from different sample groups were collected for Exploratory Factor Analysis (EFA) and Confirmatory Factor Analysis (CFA). In the first phase of the study, data were collected from 333 students studying at different schools in Ağrı city center during the fall semester of 2018-2019 academic year for EFA. In the second phase of the study, data were collected from a total of 282 students from different schools in Ağr city center during the same period for CFA. As a result, the research group consisted of 615 students.

Some of the items of anxiety scale related to the visual arts course developed by Hiçyllmaz, İnam Karahan \& Adanir(2018) for secondary school students were changed and added to the item pool. Also studies by Büyüköztürk (1997); Özdemir and Gür (2011); Öner and Le Compte (1998); Kağıtçı and Kurbanoğlu (2013); Yildirim (2015) was used to create a pool of 38 items in 5-point Likert type. The opinions of 2 Measurement and Evaluation, 2 Turkish Language and Literature and 2 Visual Arts Education experts were asked about the item pool. Expert evaluation was performed as panel discussion. In line with the opinions of the experts, 6 items were excluded from the scale. Afterwards, a pre-testing application determined as a draft form with 23 items was applied on 30 students. As a result of the application, no defect was detected. The draft form was then applied to the scale development sample.

Before the item analysis, the data collected were analyzed whether they show a normal distribution. According to the total scores in the scale, the skewness value is .482 and the kurtosis value is .425 . First, item total correlations were examined in item analysis. It was found that an item had a value of less than 0.30 and was excluded from the scale. Then, the significance test of the difference between the lower $27 \%$ and the upper $27 \%$ groups was determined according to the total scores of the scale. These values were found to be significant at $\mathrm{p}<.001$ level.

Before EFA analysis, it was examined whether the data collected was sufficient for factor analysis. The KMO value was .884 and the Barlett's test value was $(x 2=2096,752 ; p=0,000)$. In order to determine the size of the scale, "Total Variance Explained" table and "Scree Plot" chart were examined. In this respect, it was found that the scale is a two-factor scale. Then, CFA was applied by using Varimax axis rotation technique. In the next step, the rotated basic components analysis was performed to determine under which factors the item were collected. In this analysis, it was considered that the factor load value of each item in the scale was 0.60 and above. It was also examined whether the items in the scale were overlapping. As a result of these analyzes, it is seen that the scale had two dimensions.

The first dimension was named as "anxiety towards the course", and the second dimension was named as "the anxiety towards the process." It is seen that the first dimension consists of 6 items and the factor load value is between .620 and .818 , and the second dimension consists of 6 items and it has a factor load value between .611 and .773. Factor common variances were observed to be between .377 and .675 . As a result of the analyzes, it was seen that the sacle explains $51,338 \%$ of the total variance. In addition, it was determined that the eigenvalues of each dimension were greater than 1 and had a variance of $33,541 \%$ and $17,797 \%$, respectively.

In the first stage of the CFA analysis, the significance levels of $t$ values and error variances were examined. It was found that $t$ values were significant at the level of 0.01 and error variances ranged between 0.35 and 0.74 . Then, modification suggestions were examined. Following the two modifications made in this direction, the average root mean square error of approximation (RMSEA) values are examined and and the value was calculated as .075 . When the model fit indexes are examined, it is seen that RMSEA and SRMR values are acceptable. It is also seen that fit indexes such as NFI, IFI, CFI, GFI and AGFI are at excellent level. As a result of the CFA, the suitability of the factor structures obtained from EFA was determined. 
Then, Cronbach's Alpha values were examined to determine the reliability of the scale. The Cronbach Alpha coefficient of the VALAS scale was found to be .810. It was also seen that the value Factor-1 was 0,815 , the value of Factor-2 was 0,793 .

As a result, it was thought that the VALAS scale had a high reliability criterion, that it could be used in a reliable and valid way to determine the anxiety level related to the course in secondary school students and could be a source for more detailed research. When the literature is examined, it is seen that there are very few measurement tools to determine the anxiety towards visual arts lesson. In this case, it is thought that this study can fill this gap in the literature and contribute to different studies to be conducted.

Keywords: Visual Arts, Anxiety Scale, Scale Development, Validity, Reliability.

Öz: Bu çalışmada, ortaokul öğrencilerinin görsel sanatlar dersine yönelik kaygılarını belirlemek amacıyla geçerliliği ve güvenirliği sağlanmış bir ölçek geliştirme amaçlanmıştır. 5'li likert tipinde ve 23 maddeden oluşan taslak görsel sanatlar dersi kaygı ölçeği (GSDKÖ), 2018-2019 eğitim-öğretim yılı güz döneminde Ağrı ili merkezinde bulunan farklı okullarda 5, 6, 7 ve 8. sinıflarda öğrenim gören toplam 333 öğrenciye uygulanmıştır. Açımlayıcı faktör analizinin (AFA) ardından 12 maddeden ve iki alt boyuttan meydana gelen bir ölçme aracı elde edilmiştir. Birinci boyutu "Derse yönelik kaygı" ikinci boyuttu ise "Sürece yönelik kaygı" olarak adlandırılmıştır. Birinci boyutun 6 maddeden oluştuğu ve ,620 ile ,818 arasında faktör yük değeri aldığı; ikinci boyutun ise 6 maddeden meydana geldiği ve ,611 ile ,773 arasında faktör yük değeri aldığı görülmektedir. Faktör ortak varyansları ,377 ile ,675 arasında değiştiği gözlemlenmiş̧tir. Analizler sonucunda belirlenen ölçeğin toplam varyansının \%51,338'ini açıladığı görülmüştür. Aynı zamanda her bir boyutun öz değerinin 1'den büyük ve sırasıyla \%33,541, \%17,797 varyansa sahip olduğu belirlenmiştir. Belirlenen yapının ne derecede doğruladığını belirlemek amacıyla doğrulayıcı Faktör Analizi (DFA) yapılmıştır. Bu doğrultuda DFA için 282 kişilik farklı bir öğrenci grubundan veriler toplanmıştır. Sonuç olarak araştırmanın çalışma grubu 615 öğrenciden oluşmaktadır. DFA sonucunda AFA'dan elde edilen faktör yapıların uygunluğu ortaya konmuştur. GSDK ölçeğine ait Cronbach Alfa katsayısı ,810 olarak bulunmuştur.

Anahtar Kelimeler: Görsel Sanatlar, Kaygı Ölçeği, Ölçek Geliştirme, Geçerlik, Güvenirlik.

\section{Giriş}

Makale Sanat, bilgilendirici, bilinçlendirici, eğitici, arındırıcı, yüceltici yönleriyle eğitimin temel konu alanları arasında yer almaktadır. Sanatsal öğrenme sürecinde düşünme eylemden, eleştiri üründen, yaratıcılık bilgiden ayrılmaz. Sanat eğitimi, deneme, bulma, yargılama, eleştirme, çıkarımda bulunma gibi önemli süreç becerilerini bünyesinde barındırır (Yılmaz, 2010). Sanat eğitimi yoluyla öğrenci bilişsel yetileri, düşünme kapasitesi, estetik bağlamda eleștirel becerisi gelişir. Çevresini eleştirebilen, araştıran sorgulayan, değerler yaratan, cehalete karşı duran bireyler yetiştirir (Kırışoğlu, 2014). Bu yönü ile sanat eğitimi genel eğitim sürecinin önemli bir kısmını teşkil etmektedir. Bununla beraber sanatın bir özgünlük ve bireysel yaratıcılık noktasını dikkate alırsak sanat eğitiminin kendine özgü ve çok özel kural ve ilkelerinin olduğunu göz önünde bulundurmak gerekmektedir. Bu nedenle sanat eğitiminin genel eğitim içerisindeki yerinin çok iyi belirlenmesi gerekmektedir (Artut, 2001). Sanat eğitimi, diğer konu alanları gibi örgün eğitim kurumlarında zaman ve mekânla sınırlı bir derstir. Fakat sınırlı süre, sınırlı mekan uygulama ağırlıklı ve yaratıcılık etkinliklerinin yoğun olarak yer aldığı bir alan için uygun değildir. Sanat eğitiminin her yönden diğer konu alanlarından farklılığına ve özelliğine karşın bu sınırlılıkların öğretim açısından en etkin bir şekilde kullanılması çeşitli güçlükleri de beraberinde getirmektedir (Kırışoğlu, 2009).

Sanat eğitimi süreci içerisinde öğrenci ile eser arasında gelișen muazzam yaratıcı etkinlikler silsilesi görülmektedir. Öğrenci eserini oluşturan renk, çizgi, nokta, doku, boşluk, gibi plastik sanatları öğelerini tekrar, zitlık, denge, uyum, birlik gibi ilkeleri dikkate alarak sınırsız bir kombinasyon içerisinde bir araya getirir. Ayrıca öğrenci bu süreç içerisinde kullanacağı malzemeyi keserek, katlayarak, bir araya getirerek boyamalar yaparken malzemeyi doğru ve ekonomik 
kullanmayı, arkadaşları ile paylaşmayı, arkadaşları ile uyum içerisinde çalışmayı öğrenmektedir. Fakat bu yaratıcı, öğretici ve eğlenceli süreç içerisinde doğru mekânda yapılmayan, yeterince sürenin verilmediği etkinlikler, çoğu kez sanatsal öğrenmenin üstün bir yetenek ile ilişkilendirildiği bu süreç öğrencide hiç kuşkusuz bazı kaygıları da beraberinde getirmektedir. Öğrenci ortaya koyduğu ürünün yeterince sanatsal olmadığından kaygı duymaktadır. Kimi öğrenciler eseri yetiştirememekten, kimi öğrenci eserinin beğenilmeyeceğinde kimi öğrenci ise kirlenmekten kaygılanmaktadır. Bu doğrultuda öğrencilerin Görsel Sanatlar dersine ilişkin kaygılarının sanatsal gelişimlerine ve performanslarına önemli bir etkisi olduğu düşünülmektedir.

Türk dil kurumu kaygıyı, bireylerin, toplumsal kümelerin herhangi bir güçlü istek ya da güdülerinin gerçekleşememesi olasılığı karşısında duydukları tedirginlik üzüntü, endişe duyulan düşünce, tasa olarak tanımlamaktadır (tdk.gov.tr, 2019). Her ne kadar kimi tanımlarda bireyi dürtükleyerek yapıcı davranışlara iten, dişardan gelen tehlikelere karşı bireyi uyaran bir duygu olarak tanımlansa (Çavuş ve Günbatar, 2008) da kaygı, yaşamımızı olumsuz etkileyen, bireyde bir stres, korku, endişe oluşturarak öğrenmemizi güçleştiren istemediğimiz bir durumdur.

Kaygı bireyin temel duygularından biri olan korkunun daha yaygınlaşmış ve kaynağı, şiddeti ve süresi belli olmayan şeklidir. Bireyin içinde bulunduğu belirsizlik durumu, güvende olamama, özgüven eksikliği gibi duygular kişide kaygı oluşturur. Bazılarında kaygı yalnızca içinde bulunduğu durumda görülürken; bazıları için sürekli ve her durumda görülmektedir. Günlük yaşamda kaygı her bireyin belli durumlarda karşılaştı̆̆1 bilinmektedir. Optimum düzeyde bir kaygının çeşitli yararları olacaktır. Fakat kaygı bireyin günlük yaşamını zorlaştırıyor ve onun özgürce hareket etmesini kısıtllyorsa kayg1 baş edilmesi gereken bir problem durumundadır (Y1lmaz, 2010).

İlgili literatür incelediğinde farklı disiplinlere yönelik birçok kaygı ölçeğinin bulunduğu görülmüştür (Özdemir ve Gür, 2011; Kağıtçı ve Kurbanoğlu, 2013; Mutlu ve söylemez, 2018; Yıldırım, 2015). Ayrıca Türkiye'de sınırlı sayıda görsel sanatlar dersine yönelik kaygı araştırması vardır (Dilmaç, 2010; Hiçyılmaz, İnam Karahan ve Adanır, 2018; Temiz, 2011; Yurdakul, 2006). Ancak ortaokul öğrencilerinin görsel sanatlar dersine ilişkin kaygı düzeylerini belirleyen bir ölçeğe rastlanmamıştır. Bu nedenle ortaokul öğrencilerine yönelik GSDK ölçeğinin geliştirmesi faydalı olabileceği döşünülmektdir. Bu kapsamda araştırmada, ortaokul öğrencilerinin görsel sanatlar dersine ilişkin kaygı düzeylerini değerlendirebilecek bir ölçek geliştirilmesi amaçlanmıştır.

\section{Yöntem}

$\mathrm{Bu}$ çalışma, ortaokul öğrencilerinin görsel sanatlar dersine ilişkin kaygılarını değerlendirebilecek bir ölçek geliştirme araştırmasıdır.

\section{Çalışma Grubu}

$\mathrm{Bu}$ çalışmada araştırmanın amacına bağlı olarak AFA ve DFA gerçekleştirmek için farklı örneklem grubundan veriler toplanmıştır. Araştırmanın birinci aşamasında AFA için 2018-2019 eğitim-öğretim yılı güz döneminde Ağrı ili merkezinde bulunan farklı okullarda öğrenim gören toplam 333 öğrenciden veriler toplanmıştır. Bu öğrencilerin 186's1 (\%55,9) kız 147'si $(\% 44,1)$ ise erkektir. Öğrencilerin 70'i (\%21) 5. sinıf, 91'i, (\%27,3) 6. sinıf, 111'i $(\% 33,3)$ 7. sinıf ve 61'i $(\% 18,3)$ ise 8 . sinıfta öğrenim görmektedir.

Araştırmanın İkinci aşamasında ise DFA için aynı dönemde Ağnı ili merkezinde farklı okullarda öğrenim gören toplam 282 öğrenciden veri toplanmıştır. Bu öğrencilerin 113’ü $(\% 47,2)$ k1z 149'u $(\% 52,8)$ ise erkektir. Öğrencilerin 31'i (\%11) 5. sinıf, 73'ü, $(\% 25,9)$ 6. sinıf, 138'i $(\% 48,9)$ 7. sınıf ve $40{ }^{\prime} 1(\% 14,2)$ ise 8. sınıfta öğrenim görmektedir. Sonuç olarak araştırmanın çalışma grubu 615 öğrenciden oluşmaktadır. Ölçek geliştirme araştırmalarında çalışma grubunun sayısı hala tartışma konusudur. Bazı araştırmacılar, geliştirilmekte olan ölçekte yer alan katılımcı sayısının, madde sayısının en az 5 katı kadar olması gerektiğini dile getirmektedir (Bryman ve 
Cramer, 1999; Seçer, 2013). Buradan hareketle AFA ve DFA analizleri için örneklem büyüklüğün yeterli olduğu düşünülmektedir. Ayrıca öğrenciler, gönüllülük esasına dayanılarak çalışma grubuna dâhil edilmiştir. Çalışma grubuna ait bilgiler ayrıntılı bir şekilde Tablo 1'de sunulmuştur.

Tablo 1: Çalışma grubu ile ilgili demografik bilgilerin dağılımları

\begin{tabular}{|c|c|c|c|c|}
\hline & \multicolumn{2}{|c|}{ Değişkenler } & \multirow{2}{*}{$\frac{\mathrm{n}}{186}$} & \multirow{2}{*}{$\begin{array}{c}\% \% \\
55,9\end{array}$} \\
\hline \multirow{7}{*}{ AFA çalışma grubu } & \multirow{2}{*}{ Cinsiyet } & Erkek & & \\
\hline & & $\mathrm{K} 1 \mathrm{z}$ & 147 & 44,1 \\
\hline & \multirow{4}{*}{ Sinıf düzeyi } & 5. Sinif & 70 & 21,0 \\
\hline & & 6. Sinif & 91 & 27,3 \\
\hline & & 7. Sinif & 111 & 33,3 \\
\hline & & 8. Sinif & 61 & 18,3 \\
\hline & Toplam & & 333 & 100,0 \\
\hline \multirow{7}{*}{ DFA çalışma grubu } & \multirow[t]{2}{*}{ Cinsiyet } & Erkek & 133 & 47,2 \\
\hline & & $\mathrm{K} 1 \mathrm{z}$ & 149 & 52,8 \\
\hline & \multirow[t]{4}{*}{ Sınıf düzeyi } & 5. Sinif & 31 & 11,0 \\
\hline & & 6. Sinıf & 73 & 25,9 \\
\hline & & 7. Sinif & 138 & 48,9 \\
\hline & & 8. Sinif & 40 & 14,2 \\
\hline & Toplam & & 282 & 100,0 \\
\hline
\end{tabular}

\section{Ölçek Geliştirme Süreci}

\section{Madde Havuzunun Oluşturulması}

İlgili literatür tümdengelim anlayışı ile incelenmiştir. Hiçyılmaz, İnam, Karahan ve Adanır (2018) tarafından ortaöğretim öğrencilerine yönelik geliştirilen görsel sanatlar dersine yönelik kaygı ölçeğinin bazı maddeleri üzerinde tartışılarak madde havuzuna eklenmiştir. Ayrıca Büyüköztürk (1997); Özdemir ve Gür (2011); Öner ve Le Compte (1998); Kağıtçı ve Kurbanoğlu (2013); Yıldırım (2015) araştırmalardan yararlanılarak kaygı ifadelerinin belirlenmesinde kullanılmıştır. Bu doğrultuda 38 madede oluşan bir madde havuzu oluşturulmuştur. Ölçekte yer alan maddeler Likert tipi beşli dereceleme; "Tamamen katılıyorum", "Katıllyorum", "Kararsızım", "Katılmıyorum" ve "Hiç katılmıyorum" biçiminde katılım düzeyi belirlenmiştir.

\section{Uzman Görüşünün Alınması}

Oluşturulan taslak formun kapsam geçerliliğini belirlemek üzere uzman görüşüne başvurulmuştur. Madde havuzu 2 Ölçme ve Değerlendirme, 2 Türk Dili ve Edebiyatı ve 2 görsel sanatlar Eğitimi alan uzmanının görüşüne sunulmuştur. $\mathrm{Bu}$ aşamada uzmanların madde havuzundaki ifadelerin yanlış anlamlara sebep olabilecek yönlerin bulunup bulunmadığı ve kayg1 ifadelerinin araştırmanın amacına uygunluğu gibi çeşitli açıdan değerlendirmiştir. Uzman değerlendirilmesi sözel panel şeklinde gerçekleştirilmiştir. Uzmanlar hemfikir oluncaya kadar panel devam etmiş̧ir. Bu doğrultuda 15 madde elenmiş 6 madde ise düzeltilmiştir. Sonuç olarak 23 madde oluşan bir taslak form oluşturulmuştur. 


\section{Ön Deneme Uygulaması}

Uzman görüşleri doğrultusunda 23 madde olarak belirlenen taslak form kullanarak 30 öğrenci ile ön deneme uygulaması yapılmıştır. Taslak formun öğrenciler açısından anlaşılabilirliğine bakılmıştır. Uygulama sonucunda herhangi bir aksaklık tespit edilmemiştir. Daha sonra taslak form ölçek geliştirme örneklemine uygulanmıştır.

\section{Verilerin Analizi}

GSDK ölçeğinin geliştirme sürecinde veriler kodlanarak SPSS 17.0 paket programın yüklenmiştir. GSDK ölçeğinde yer alan maddelere verilen yanıtlar, kaygı durumunu yansıtan ifadeler olduğundan dolayı ters kodlama yapılmıştır. Daha sonra ölçeğin yapısını belirlemek amacıyla bu program aracılı̆̆ıyla açımlayıcı faktör analizi (AFA) yapılmıştır. Bir sonraki aşamada belirlenen bu yapıyı doğrulamak için doğrulayıcı faktör analizinin (DFA) yapılmasına karar verilmiştir. $\mathrm{Bu}$ amaç doğrultusunda farkı örneklem grubundan veriler toplanmış LISER 8.80 paket programına kaydedilmiştir.

\section{Bulgular}

Bu bölümde ortaokul öğrencilerinin görsel sanatlar dersine yönelik kaygılarını belirlemeye yönelik geliştirilen ölçeğin analizleri alt başlıklar halinde sunulmuştur. Madde analizine başlamadan önce toplanan verilerin normal dağılıp dağılmadığına bakılmıştır. $\mathrm{Bu}$ doğrultuda ölçekteki toplam puanlara göre çarpıklık (skewness) değerinin ,482 ve basıklık (kurtosis) değerinin ise -,425 olduğu görülmektedir. "Çarpıklık katsayısının $\pm 1,0$ sınırları içinde kalması, puanların normalden aşırı bir sapma göstermediği şeklinde yorumlanabilir” (Büyüköztürk, Çokluk ve Köklü, 2016 s. 48).

\section{Madde Analizi}

Madde analizlerinde "madde toplam korelasyonları en düşük olanlar ilk önce elenebilir" (DeVelis, 2014 s. 112). Dolayısıyla madde toplam korelasyonu 0,30 ve üzeri olan maddelerin iyi bir madde olarak kabul edilmiş 0,30 altı olan maddeler elenmiştir. Ayrıca GSDKÖ’nün toplam puanlarına göre belirlenen alt $\% 27$ ve üst \%27'lik gurupların arasındaki farkın önemlilik testine bakılmıştır. Ölçeğinin madde analiz sonuçları Tablo 2'de sunulmuştur.

Tablo 2: Ölçeğin madde analizi sonuçları

\begin{tabular}{ccc}
\hline & & $\mathrm{t}$ \\
Madde No & Madde Toplam Korelasyonları & (Alt \% 27-Üst \%27)** \\
\hline M1 &, 360 & $6,964^{* * *}$ \\
M2 &, 445 & $8,749^{* * *}$ \\
M3 &, 453 & $8,243^{* * *}$ \\
M4 &, 441 & $7,307^{* * *}$ \\
M5 &, 491 & $8,328^{* * *}$ \\
M6 &, 336 & $7,051^{* * *}$ \\
M7 &, 436 & $8,631^{* * *}$ \\
M8 &, 479 & $8,552^{* * *}$ \\
M9 &, $\mathbf{2 6 8}$ & $6,129^{* * *}$ \\
M10 &, 366 & $9,397^{* * *}$ \\
M11 &, 493 & $8,552^{* * *}$ \\
M12 &, 425 & $9,136^{* * *}$ \\
\hline
\end{tabular}

Turkish Studies - Education, 15(2) 


\begin{tabular}{llc}
\hline M13 &, 419 & $10,632^{* * *}$ \\
M14 &, 543 & $12,868^{* * *}$ \\
M15 &, 521 & $10,338^{* * *}$ \\
M16 &, 418 & $7,134^{* * *}$ \\
M17 &, 445 & $10,527^{* * *}$ \\
M18 &, 311 & $8,354^{* * *}$ \\
M19 &, 433 & $10,229^{* * *}$ \\
M20 &, 565 & $13,731^{* * *}$ \\
M21 &, 499 & $13,466^{* * *}$ \\
M22 &, 515 & $15,245^{* * *}$ \\
M23 &, 365 & $8,919^{* * *}$ \\
\hline
\end{tabular}

$\mathrm{n}=333,{ }^{* * *} \mathrm{p}<0,01$

Tablo 2 incelendiğinde, M9'ün 0,30'un altında değer aldığı görülmüş ve bu madde ölçekten çıkarılmıştır. Tablo incelenmeye devam edildiğinde 23 maddenin $p<.001$ düzeyinde anlamlı olduğu görülmüştür.

\section{Açımlayıcı Faktör Analizi}

AFA, "Bir ölçme aracında yer alan maddelerin ( değişkenlerin) kaç alt başlık altında toplanabileceğini ve aralarında ne tür bir ilişki olduğunu belirtme tekniğidir" (Seçer, 2013 s. 117). AFA analizine başlamadan önce toplanan verilerin faktör analizi için yeterli olup olmadığına bakılmıştır. Bu doğrultuda Kaiser- Meyer-Olkin (KMO) ve Bartlett's küresellik testi sonuçlarına bakılmıştır. KMO değeri için ,884 ve Barlett's test değerinin ise $\left(x^{2}=2096,752 ; p=0,000\right)$ olduğu görülmüştür. KMO değerinin " $0,80-0,90$ arası=çok iyi” şeklinde sınıflandırılabilir (Field, 2002). Bu doğrultuda çalışma grubun yeterli olduğu dolayısıyla veriler faktör analizine uygun olduğu ve KMO değerinin çok iyi sınıflandırmasına karşılık geldiği söylenebilir.

\section{Faktörlerin elde edilmesi}

Ortaokul öğrencilerinin görsel sanatlar dersine yönelik kaygı ölçeğine ilişkin ilk olarak maddelerin ortak varyans değerlerine bakılmıștır. Daha sonra faktör yük değerleri incelenmiștir. Herhangi bir problemin olmadığını görüldükten sonra faktör sayısı belirleme aşamasına geçilmiștir. Ölçeğin kaç boyutlu olduğunu belirlemek için "Total Variance Explained" tablosunu ve "Scree Plot” grafiğinin incelenmesine karar verilmiştir. Bu analizlere ilişkin değerler Tablo 3 'te ve şekil 1 'de verilmiştir.

Tablo 3: Ortaokul öğrencilerinin görsel sanatlar dersine yönelik kaygı ölçeğin taslak faktör yapısı

\begin{tabular}{cccc}
\hline Faktör & Özdeğer & $\begin{array}{c}\text { Varyans } \\
\%\end{array}$ & $\begin{array}{c}\text { Toplam varyans } \\
\%\end{array}$ \\
\hline 1 & 5,984 & 27,200 & 27,200 \\
2 & 2,509 & 11,403 & 38,603 \\
3 & 1,140 & 5,181 & 43,784 \\
4 & 1,064 & 4,838 & 48,622 \\
5 & 1,038 & 4,716 & 53,339 \\
\hline
\end{tabular}




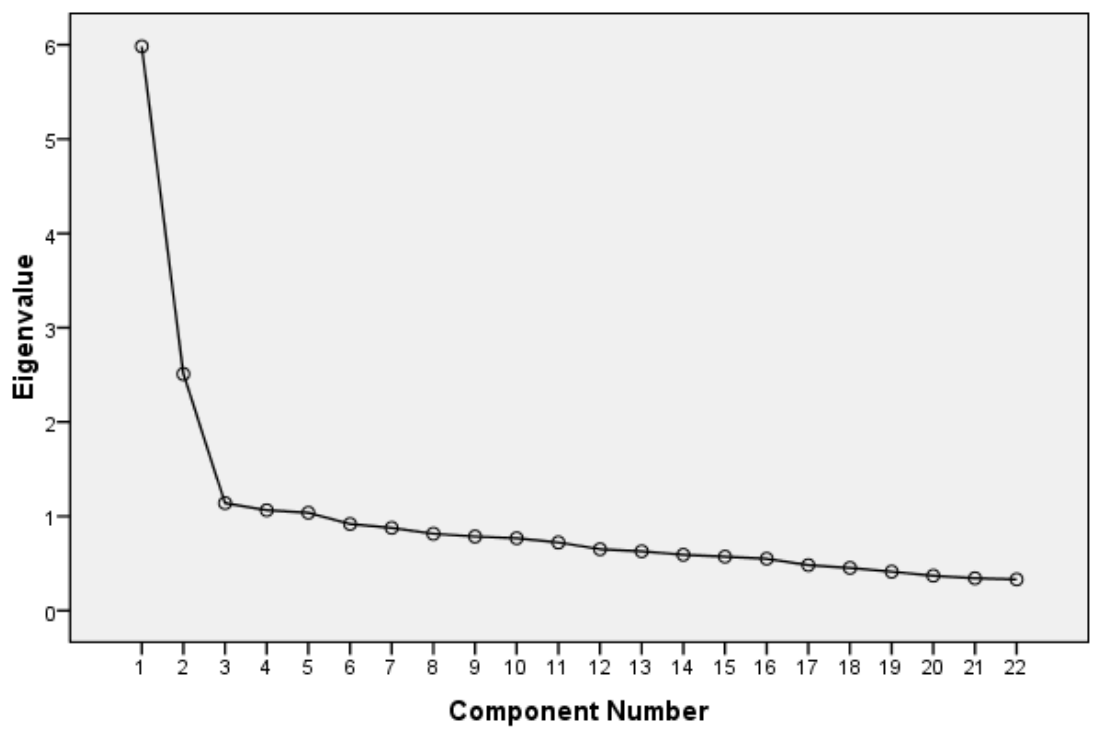

Şekil 1: Saçılma grafiği

Çizgi grafiği incelendiğinde, ikinci faktörden sonra eğimin azaldığı ve aralarındaki mesafelerin çok benzer olduğu görülmektedir. Ayrıca tablo 3’teki bilgiler çizgi grafiğini doğrular niteliktedir. İlk iki faktörün önemli ölçüde varyansa katkı sağladığı görülmektedir. Dolayısıyla bu ölçek 2 faktörlü bir yapı meydana getirebileceği fikrine ulaşılmıştır. Daha sonra Varimax eksen döndürme tekniği kullanılarak AFA'ya uygulanmıştır. Bu döndürme tekniği, çok faktörlü yapıların meydana geldiği durumlarda kullanılabilir (Büyüköztürük, 2002). Bu doğrultuda az sayıda değişkenle faktör varyanslarının en yüksek değeri almasını sağlamak amacıyla Varimax eksen döndürme tekniği seçilmiştir. Bir sonraki aşamada maddelerin hangi faktörler altında toplandığını belirlemek amacıyla döndürülmüş temel bileşenler analizi yapılmıştır. Bu analizde ölçekte yer alan her bir maddenin faktör yük değeri 0,60 ve üstü olmasına dikkat edilmiştir. 0,60 ve üstü yüksek yük değerleri olarak kabul edilmektedir (Çokluk vd., 2016). Daha sonraki aşamada binişik madde olup olmadığına bakılmıştır. Binişik madde iki faktördeki yük değerleri arasındaki farkın 0,10'dan az olması şeklinde tanımlanabilir (Büyüköztürk, 2008; Seçer, 2013). Bu doğrultuda yapılan analizlerde "kesin bir kural olmamakla birlikte, madde çıkarılmasına kararı verilmiş ise binişik maddelerden başlanması tercih edilebilir" (Çokluk vd., 2016 s. 234). Bu doğrultuda birinci aşamada "M12" binişik madde olarak kabul edilip analiz dışı bırakılmıştır. İkinci aşamada "M1, M6, M10, M13, M14, M16, M17, M19, M24" maddelerinin 0,60 düzeyini karş1layamadığından analiz dışı bırakılmıştır.

Ortaokul öğrencilerinin görsel sanatlar dersine yönelik kaygı ölçeğinin çalışmayan maddelerin belirlenip tamamen analiz dışı bırakılmasının ardından nihai ölçeğin faktör ortak varyansları ve döndürme sonrası yük değerleri Tablo 4'te sunulmuştur. 
Tablo 4: Ölçek Maddelerinin faktör ortak varyansları ve döndürme sonrası yük değerleri

\begin{tabular}{|c|c|c|c|}
\hline \multirow[t]{2}{*}{ Madde No } & \multirow[t]{2}{*}{ Faktör oratak varyansı } & \multicolumn{2}{|c|}{ Döndürme sonrası yük değeri } \\
\hline & & Faktör 1 & Faktör 2 \\
\hline M5 & ,675 &, 818 & \\
\hline M4 &, 594 &, 767 & \\
\hline M3 &, 541 &, 731 & \\
\hline M2 & ,499 & ,696 & \\
\hline M7 & ,446 & ,656 & \\
\hline M8 &, 430 & ,620 & \\
\hline M23 & ,603 & & ,773 \\
\hline M22 &, 548 & & ,737 \\
\hline M21 &, 556 & &, 721 \\
\hline M20 &, 455 & & ,667 \\
\hline M15 & ,438 & & ,634 \\
\hline M18 &, 377 & & 611 \\
\hline \multirow[t]{2}{*}{ Varyans } & & 33,541 & 17,797 \\
\hline & & Toplam varyans: & 51,338 \\
\hline
\end{tabular}

Tablo 4 incelendiğinde ortaokul öğrencilerinin görsel sanatlar dersine yönelik kayg1 ölçeğinin iki boyutta toplandığı görülmektedir. Birinci boyutu "Derse yönelik kaygı" ikinci boyuttu ise "Sürece yönelik kaygı" olarak adlandırılmıştır. Birinci boyutun 6 maddeden oluştuğu ve ,620 ile ,818 arasında faktör yük değerleri aldığı; ikinci boyutun ise 6 maddeden meydana geldiği ve ,611 ile ,773 arasında faktör yük değerleri aldığı görülmektedir. Faktör ortak varyanslarının ,377 ile ,675 arasında değiştiği gözlemlenmiştir. Analizler sonucunda belirlenen ölçeğin toplam varyansının \% 51,338'ini açıkladığ 1 görülmüştür. Aynı zamanda her bir boyutun öz değerinin 1'den büyük ve sırasıyla \% 33,541, \% 17,797 varyansa sahip olduğu belirlenmiştir. Bu değerlerin ölçek geliştirme çalışmaları için yeterli olduğu düşünülmektedir (Büyüköztürk, 2008; Özdamar, 2016; Tabachnick ve Fidell, 1996).

\section{Doğrulayıcı Faktör Analizi}

GSDKÖ’nün yapı geçerliliğine yönelik kanıt elde etmek amacıyla gerçekleştirilen AFA için 333 öğrenciden veri toplanmıştır. Analizler sonucunda ölçeğin faktör yapısı belirlenmiştir. Belirlenen yapının ne derecede doğruladığını ortaya çıkarmak amacıyla DFA yapılmışıtır. DFA, belirlenen bir yapının bir model olarak doğruluğunun test edilmesi amacıyla yapılan analizlerdir (Çokluk vd., 2016). Literatürde DFA için yeni bir örneklem grubu önerilmektedir (Huck, 2012; Worthington ve Whittaker, 2006). Bu doğrultuda 282 kişilik farklı bir öğrenci grubundan veriler toplanmıştır. Veriler üzerinde uç değerler, kayıp veriler ile ilgili herhangi bir sıkıntı olmadığı gözlemlenmiştir. Analizlere başlamadan önce KMO değerine bakılmıştır. KMO'nun ,876 değer aldığı görülmüştür. Bartlett Küresellik Testi'nin $x^{2}=1468,069 ; p=0,000$ olduğu görülmüştür. Bu doğrultuda verilerin DFA'ya uygun olduğu söylenebilir. Ayrıca verilerin toplam puanlara göre çarpıklık (skewness) değerinin ,864 ve basıklık (kurtosis) değerinin ise -,137 olduğu görülmektedir. $\mathrm{Bu}$ doğrultuda verilerin normal dağılım sağladığı söylenebilir. 
Analizin ilk aşamasında " $\mathrm{t}$ " değerlerinin anlamlılık düzeylerine ve hata varyanslarına bakılmıştır. " $t$ " değerlerinin 0,01 düzeyinde anlamlı olduğu ve hata varyanslarının 0,35 ile 0,74 değerleri arasında değiştiği görülmüş̧ür. Daha sonra modifikasyon önerileri incelenmiştir. Bu doğrultuda yapılan iki modifikasyon ardında Yaklaşık Hataların Ortalama Karekökü (RMSEA) değerlerine bakılmış ve değerin ,075 olarak hesaplandığ 1 görülmüştür. Ortaokul öğrencilerinin görsel sanatlar dersine yönelik kaygı ölçeğin birinci düzey DFA sonuçlarına ilişkin yol şeması Şekil 2'de verilmiştir.

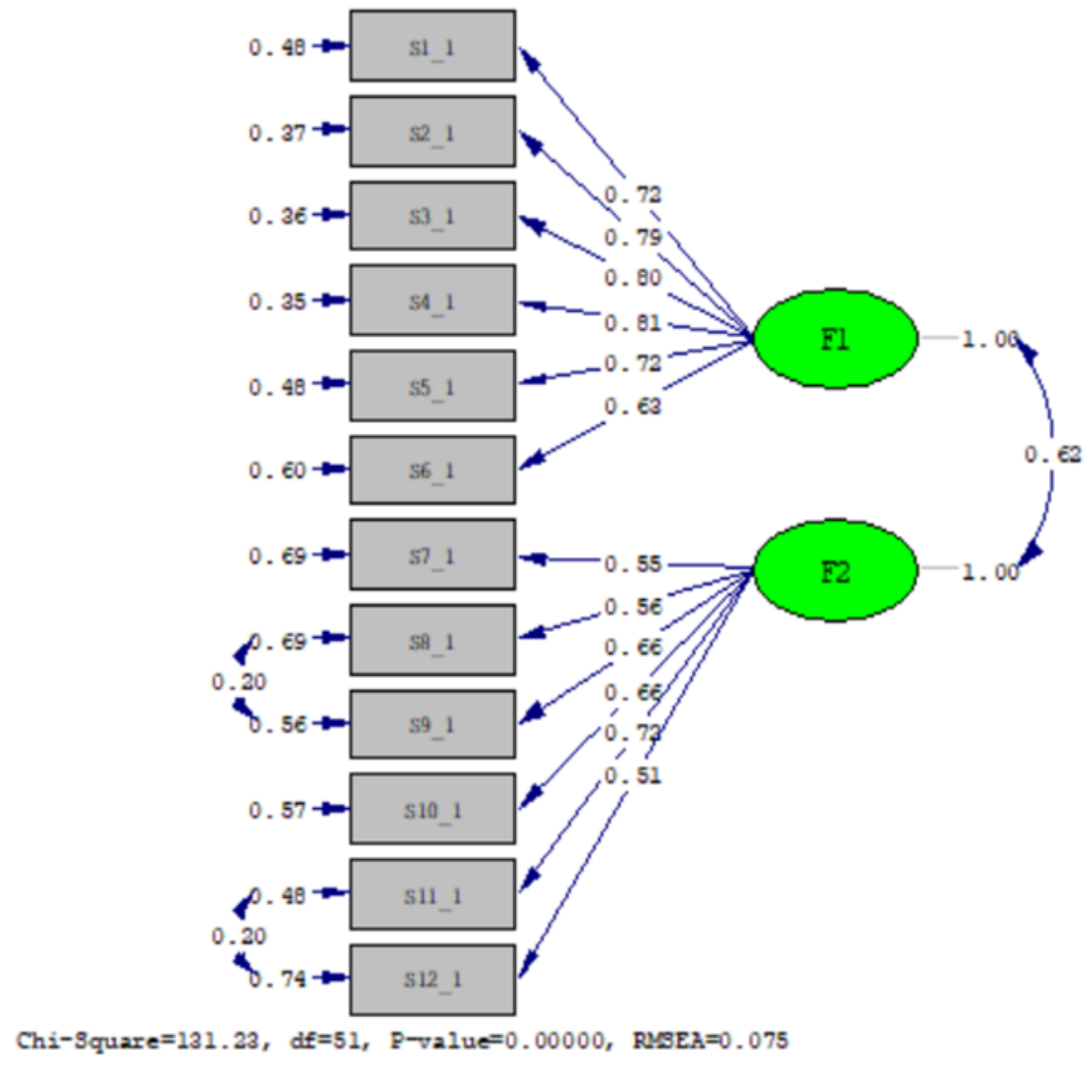

Şekil 2:. Ortaokul öğrencilerinin görsel sanatlar dersine yönelik kaygı ölçeğin birinci düzey dfa sonuçlarına ilişkin yol şeması

" $t$ " değerleri ve hata varyanslarında herhangi bir problem olmadığ 1 anlaşılmıştır. Bir sonraki aşama $\mathrm{p}$ değerine bakılmıştır. $\mathrm{P}(\mathrm{x} 2, \mathrm{p}>0.5)$ değerinin normal olduğu görülmüştür. Aynı zamanda $\mathrm{x} 2 / \mathrm{sd}$ oranının 3'ün altında olmasının mükemmel düzeyde uyum değeri verdiği söylenebilir (Çokluk vd., 2016). Daha sonra diğer model uyum indekslerinin incelenmesine geçilmiştir. Bu değerler Tablo 5'te sunulmuştur. 
Tablo 5: GSDKÖ İçin uyum iyiliği testlerine ilişkin değerler

\begin{tabular}{lcccc}
\hline Uyum istatistikleri & Kabul edilebilir sınır & $\begin{array}{c}\text { Mükemmel uyum } \\
\text { sinırı }\end{array}$ & Kaynak & $\begin{array}{c}\text { Ölçeğin I. düzey } \\
\text { uyum değerleri }\end{array}$ \\
\hline RMSEA & $=, 50 \mathrm{ve}=, 80$ & $=, 000 \mathrm{ve}<, 050$ arası & (Seçer, 2013) &, 075 \\
SRMR & $=, 50 \mathrm{ve}=, 80$ & $=, 000 \mathrm{ve}<, 050$ aras1 & $\begin{array}{c}\text { (Seçer, 2013) } \\
\text { (Gürbüz ve Şahin, }\end{array}$ &, 056 \\
NFI & $>, 90$ & $>, 95$ & $2015)$ &, 95 \\
IFI & $>, 97$ & $>, 95$ & $($ Seçer, 2013) &, 97 \\
CFI & $>, 90$ & $>, 95$ & (Gürbüz ve Şahin, & 2015) \\
GFI & $>, 85$ & $>, 90$ & (Seçer, 2013) &, 97 \\
AGFI & $>, 85$ & $>, 90$ & (Seçer, 2013) &, 93
\end{tabular}

Tablo 5 incelendiğinde RMSEA ve SRMR değerleri kabul edilebilir düzeyde olduğu görülmektedir. Aynı zamanda NFI, IFI, CFI, GFI ve AGFI gibi uyum indekslerinin ise mükemmel düzeyde olduğu görülmektedir. Bu doğrultuda AFA'da elde edilen faktöriyel yapının model olarak doğrulandığı söylenebilir.

\section{Güvenirlik}

Ölçeğin geçerliliğine kanıt sunmak amacıyla uzman görüşünden yararlanılmıştır. Ayrıca madde analizi, AFA ve DFA gibi analizler yapılmıştır. Hazırlanan bir ölçme aracı geçerli olması için mutlaka güvenilir olması gerekmektedir (Özdamar, 2016). Dolayısıyla araştırmacı, ölçeğin güvenirliğini sağlamak amacıyla Cronbach Alfa tekniğini kullanmıştır. Ölçeğinin güvenilirlik değerleri Tablo 6'da verilmiştir.

Tablo 6: Ölçeğin güvenilirlik değerleri

\begin{tabular}{lcc}
\hline & Madde sayısı & Cronbach Alfa \\
\hline Testin tümü & 12 &, 810 \\
Faktör-1 & 6 &, 815 \\
Faktör-2 & 6 &, 793 \\
\hline
\end{tabular}

Tablo 6'da görüldüğü gibi, ortaokul öğrencilerinin görsel sanatlar dersine yönelik kayg1 ölçeğinin tümünden elde edilen puanların Cronbach alfa değeri ,810 olarak bulunmuştur De Vellis'e göre(2014), $\alpha=0,80$ ve üzerindeki değerler çok iyi olarak ifade etmektedir. Dolayısıyla bu bulgunun çok iyi düzeyde güvenilir ve kabul edilebilir değer olduğu söylenebilir. Ayrıca Faktör-1 0,815, Faktör-2 0,793 değerler aldığ görülmüştür. Sonuç olarak ölçeğin maddeleri birbiriyle tutarlı olduğu dolayısıyla geçerli ve güvenirliliğine yönelik kanıt elde edildiği söylenebilir.

\section{Tartışma ve Sonuç}

Sanatla uğraşan bireylerin duygu düzenleme becerileri ile kaygı düzeyleri arasında doğrudan bir ilişki bulunmaktadır (Öpöz, 2017). Bu durum öğrencinin sanatsal öğrenme sürecini ve ürünlerini olumsuz etkileyecektir. Ortaokulda öğrenim gören öğrencilerin görsel sanatlar dersine yönelik kaygı düzeylerinin geçerli ve güvenilir ölçümler yapılarak belirlenmesi, derse olan ilginin, başarının ve duygu durumlarının değerlendirilmesi açısından önemli katkılar sağlayacağı düşünülmektedir. $\mathrm{Bu}$ doğrultuda bu araştırmada ortaokul öğrencilerinin görsel sanatlar dersine ilişkin kayg1 düzeylerini değerlendirebilecek bir ölçek geliştirmesi amaçlanmıştır. $\mathrm{Bu}$ amaç doğrultusunda tümdengelim yaklaşımı yöntemi ile ilgili literatürü incelenmesi sonucunda 5 'li likert tipinde 38 madden oluşan bir madde havuzu oluşturulmuştur. Uzmanların görüşleri doğrultusunda 
15 madde elenmiş 6 madde ise düzeltilmiş̧ir. Uzman görüşleri ve ön denemelerden sonra kayg1 ölçeği gerçek gruba uygulanmıştır.

Ölçeğe ilişkin KMO değeri ,884 ve Bartlett Küresellik Testi'nin $x^{2}=2096,752 ; p=0,000$ olarak bulunmuştur. Madde toplam korelasyon analizinde, bir madde M3'ün 0,30'un altında değerler aldığı görülmüş ve bu madde ölçekten çıkarılmıştır. Çizgi grafiği ve "Total Variance Explained" tablosundan elde edilen veriler doğrultusunda iki faktörlü bir yapı meydana getirebileceği fikrine ulaşılmıştır. Daha sonra dik döndürme tekniklerinden "Varimax" yöntemi kullanarak analizler yapılmıştır. Bu analizler sonucunda 12 maddeden ve iki alt boyuttan oluşan bir ölçek elde edilmiştir. Birinci boyutu "Derse yönelik kaygı" ikinci boyuttu ise "Sürece yönelik kaygı" olarak adlandırılmıştır. Belirlenen yapının ne derecede doğruladığını belirlemek amacıyla DFA yapılmıştır. DFA sonucunda AFA'dan elde edilen faktör yapıların uygunluğu ortaya konulmuştur. GSDK ölçeğine ait Cronbach alfa katsayısı ,810 olarak bulunmuştur. Bu oran GSDK ölçeğin ortaokul düzeyindeki öğrenciler için uygun olduğu söylenebilir.

Sonuç olarak GSDK ölçeğinin yüksek düzeyde güvenirlik ölçütlerine sahip olduğu, ortaokul öğrencilerin derse yönelik kaygı düzeylerini belirlemede geçerli ve güvenilir biçimde kullanılabileceği ve daha ayrıntılı araştırmalar için kaynaklık edebileceği düşünülmüştür. Alanyazın incelendiğinde, ortaokul öğrencilerinin görsel sanatlar dersine ilişkin kaygı düzeylerini belirleyen bir ölçeğe rastlanmamıştır. Bu durumda yürüttüğümüz çalışmanın alınyazındaki bu boşluğu doldurabileceği, yapılacak olan farklı çalışmalara katkı sağlayabileceği düşünülmektedir. GSDK ölçeğin kullanılması ile ortaokul öğrencilerinin görsel sanatlar dersine yönelik kayg1 düzeylerini farklı değişkenler açsından araştırmalar yapılabilir.

\section{Kaynakça}

Artut, K. (2001). Sanat eğitimi kuramları ve yöntemleri, Ankara: Anı Yayınc1lık.

Bryman, A., \& Cramer, D. (1999). Quantitative data analysis with SPSS release 8 for windows. London and New York: Taylor \& Francis e-Library, Routledge.

Büyüköztürk, Ş. (1997). Araştırmaya yönelik kaygı ölçeğinin geliştirilmesi. Kuram ve Uygulamada Egitim Yönetimi Dergisi, 3(4), 453-464.

Büyüköztürk, Ş. (2008). Sosyal bilimler için veri analizi el kitabı (9. baskı). Ankara: Pegem Akademi Yayıncilık.

Büyüköztürk, Ş., Çokluk, Ö., \& Köklü, N. (2016). Sosyal bilimler için istatistik (18. bask1). Ankara: Pegem Akademi.

Çavuş, H., Günbatar, M.S. (2008). Bilgisayar kaygı ölçeğinin Türkçe'ye uyarlama çalışması, Gazi Ĕ̈itim Fakültesi Dergisi, 28(3), 147-163.

Çokluk, Ö., Şekercioğlu, G., \& Büyüköztürk, Ş. (2016). Sosyal bilimler için çok değiş̧kenli istatistik SPSS ve Lisrel uygulamaları (4. bask1). Ankara: Pegem Akademi.

De Vellis, R.F. (2014). Ölçek geliştirme: kuram ve uygulamalar (Ed.Tarık Totan), Ankara: Nobel Yayınc1lik.

Dilmaç, O. (2010), Görsel sanatlar öğretmeni adaylarının kaygı düzeylerinin çeşitli değiş̧kenler açısından incelenmesi. Güzel sanatlar enstitüsü dergisi, 24, 49-65.

Field, A. (2002). Discovering statistics using SPSS. London, UK: Sage

Hiçyılmaz Y., İnam Karahan Ç., \& Adanır Y., (2017). Görsel sanatlar dersine yönelik kayg1 ölçeğinin Geliştirilmesi. 26. Uluslararası Eğitim Bilimleri Kongresi, 20-23 Nisan, Antalya/ TURKEY(Tam Metin Bildiri/Sözlü Sunum, S. 289-297) 
Huck, S.W. (2012). Reading statistics and research (6th edition). Boston, MA; Pearson

Kağıtçı B., \& Kurbanoğlu N.İ. (2013). Fen ve teknoloji dersine yönelik kaygı ölçeğinin geliştirilmesi: güvenirlik ve geçerlik çalışması. Journal of Turkish Science Education, 10(3), 95-107.

Kırışoğlu, O.T. (2009). Sanat kültür yaratıcılık, Ankara: Pegem Akademi.

Kırışoğlu, O.T. (2014). Sanat bir serüven, Ankara: Pegem Akademi.

Mutlu, Y., \& Söylemez, İ. (2018). İlkokul 3. ve 4. sınıf çocukları için matematik kaygı ölçeği; güvenirlik ve geçerlik çalışması. Ekev Akademi Dergisi, 22(73), 429-440.

Öner, N. \& A. Le Compte. (1983). Durumluk sürekli kaygı envanteri el kitabı. İstanbul: Boğaziçi Üniversitesi Yayını.

Öpöz, T. (2017). Spor ve sanatla uğraşan ergenlerin duygu düzenleme becerileri, sosyal kaygı ve öfke düzeyleri arasındaki ilişki, Yayımlanmamış Yüksek Lisans Tezi, Ankara Üniversitesi Sosyal Bilimler Enstitüsü, Ankara.

Özdamar, K. (2016). Ĕ̈itim, sağllk ve davranış bilimlerinde ölçek ve test geliştirme yapısal eşitlik modellemesi. Eskişehir: Nisan.

Özdemir, E., \& Gür, H. (2011). Matematik kaygısı-endişesi ölçeğinin (MKEÖ) geçerlik ve güvenirlik çalışması. Eğitim ve Bilim, 36(161), 39-50

Seçer, İ. (2013). Spss ve Lisrel ile pratik veri analizi, analiz ve raporlaştırma. (1. baskı). Ankara: Anı Yayıncilik.

Tabachnick, B. G., \& Fidell, L. S. (1996). Using multivariate statistics. Harper Collins College Publishers: New York.

Temiz, E. (2011). Güzel sanatlar eğitimi bölümü öğretmen adaylarının mesleki kaygı düzeylerinin cinsiyet ve alan değişkenleri açısından incelenmesi. E-Journal of New World Sciences Academy, 6(2), 303-310.

Worthington, R. L., \& Whittaker, T. A. (2006). Scale development research a content analysis and recommendations for best practices. The Counseling Psychologist, 34(6), 806-838. https://doi.org/10.1177/0011000006288127

Yurdakul, T. ( 2006). Gazi üniversitesi mesleki eğitim fakültesi uygulamalı sanatlar eğitimi bilim dalı seramik eğitimi anabilim dalı öğrencilerinin işsizlik kaygıları üzerine bir araştırma, Yayımlanmış Yüksek Lisans Tezi, Gazi Üniversitesi Eğitim Bilimleri Enstitüsü, Ankara.

Yıldırım, B. (2015). Fen bilimleri öğrenme kaygı ölçeği: geçerlilik ve güvenirlik çalışması. Anemon Muş Alparslan Üniversitesi Sosyal Bilimler Dergisi, 3(1), 33-43. https://doi.org/10.18506/anemon.71733

Yılmaz, D. (2010). Okul yöneticilerinin yetki kullanımı kaygı ölçeği (OYKÖ): geçerlik ve güvenirlik çalışması, Yayımlanmamaış Yüksek Lisans Tezi, Gazi Osman Paşa Üniversitesi Sosyal Bilimler Enstitüsü, Tokat.

Yılmaz, M. (2010). Görsel sanatlar eğitiminde uygulamalar, Ankara: Data Yayınları. 